\title{
PENGEMBANGAN BUKU AJAR KETERAMPILAN MENYIMAK BERBASIS CONTEXTUAL TEACHING AND LEARNING
}

\author{
Lira Hayu Afdetis Mana ${ }^{1}$, Titiek Fujita Yusandra ${ }^{1}$, Atmazaki ${ }^{2}$, dan Syahrul Ramadhan ${ }^{2}$ \\ ${ }^{1}$ Program Studi Pendidikan Bahasa dan Sastra Indonesia STKIP PGRI Sumatera Barat \\ ${ }^{2}$ Fakultas Bahasa dan Seni Universitas Negeri Padang \\ email: liramana@gmail.com
}

\begin{abstract}
Abstrak
Penelitian ini bertujuan untuk menghasilkan buku ajar keterampilan menyimak berbasis pendekatan Contextual Teaching and Learning(CTL) yang valid, praktis, dan efektif pada Mata Kuliah Pengajaran Keterampilan Menyimak. Prosedur pengembangan produk penelitian ini berdasarkan model ADDIE (Analiyze, Design, Develop, Implement, Evaluation) dan dibatasi sampai pada tahap ketiga. Kegiatan analisis melalui dua tahap yaitu analisis masalah dan analisis kebutuhan. Validasi buku ajar dilakukan oleh ahli mata kuliah menyimak, ahli bahasa, dan ahli kegrafikaan. Kepraktisan buku ajar dilihat melalui pengisian angket kepada pengguna buku ajar yaitu dosen dan mahasiswa. Kefektifan buku ajar dilihat dari hasil aktivitas dan hasil belajar mahasiswa. Produk diujicobakan kepada mahasiswa Program Studi Pendidikan Bahasa Indonesia di STKIP PGRI Sumbar dan Universitas Negeri Padang. Berdasarkan hasil analisis kebutuhan mahasiswa dinyatakan bahwa mahasiswa memerlukan sumber belajar yang dapat menunjang keterampilan menyimak. Hasil penelitian menunjukkan bahwa buku ajar keterampilan menyimak berbasis pendekatan CTL sudah memenuhi kriteria valid baik dari segi isi maupun konstruk, praktis dari segi kemudahan dan kesesuaian waktu serta efektif untuk meningkatkan aktivitas dan hasil belajar mahasiswa.
\end{abstract}

Kata kunci: buku ajar, keterampilan menyimak, CTL

\section{DEVELOPMENT OF TEACHING SKILLS BASED ON CONTEXTUAL TEACHING AND LEARNING}

\begin{abstract}
This study was aimed at producing a valid, practical, and effective Contextual Teaching and Learning (CTL)-based Listening Skills textbook for the Listening Skills Teaching course. The procedure of developing this research product is based on the ADDIE model (Analiyze, Design, Develop, Implement, Evaluation) and limited to the third stage. Analysis activities through two stages, namely problem analysis and needs analysis. Validation of textbooks is conducted by listening subject experts, linguists and graphic experts. Practicality of textbooks is seen through filling out questionnaires to textbook users, namely lecturers and students. The effectiveness of textbooks is seen from the results of student activities and learning outcomes. The product was tested on students of the Indonesian Language Study Program at STKIP PGRI West Sumatra and Padang State University. Based on the analysis of student needs it is stated that students need learning resources that can support listening skills. The results showed that the listening skill textbook based on the CTL approach had fulfilled valid criteria both in terms of content and construct, practically in terms of ease and suitability of time and was effective in increasing student activity and learning outcomes.
\end{abstract}

Keywords: tektbooks, listening skills, CTL 


\section{PENDAHULUAN}

Salah satu mata kuliah penting yang mengalami beberapa permasalahan adalah Mata Kuliah Pengajaran Keterampilan Menyimak. Menyimak sebagai salah satu kegiatan berbahasa merupakan keterampilan yang cukup mendasar dalam aktivitas komunikasi, selain keterampilan berbahasa lain. Atmazaki (2007, p. vii) menjelaskan bahwa setiap orang sudah diberi modal berupa kemampuan mendengar, berbicara, membaca, dan menulis. Akan tetepi, keempat keterampilan itu perludikembangkan. Keterampilan menyimak adalah aktivitas yang hampir sama dengan mendengarkan. Kedua kata itu memiliki perbedaan pengertian. Rixon (Nursaid, 2001, p. 29) menyatakan bahwa mendengarkan adalah kegiatan yang bersifat ekstensif, bukan dikaitkan dengan tujuan untuk memahami ujaran, dan secara umum tidak terdapat kesulitan dalam melaksanakannya. Achsin (Nursaid \& Munaf, 2010, p. 40) mengatakan bahwa menyimak dapat dipandang sebagai kegiatan mental yang lebih aktif dari pada kegiatan mendengarkan. Mendengarkan merupakan proses aktif yang terjadi secara kompleks karena adanya rangsangan gelombang suara. Mendengar secara efektif sangat diperlukan dalam pembelajaran (Salirawati, 2008).

Achsin (Nursaid, 2001, p. 33) mengemukakan bahwa menyimak merupakan aktivitas mental yang melibatkan serangkaian proses. Proses tersebut mulai dari mengidentifikasi bunyi-bunyi atau sound identification, menyusun pemahaman dan penafsiran atau constructing process, proses penggunaan hasil pemahaman dan penafsiran atau utilization process, sampai proses penyimpangan atau storage. Menyimak sebagai salah satu keterampilan berbahasa, diperlukan dalam pembelajaran bahasa karena menyimak tidak secara langsung dapat dimiliki oleh mahasiswa, namun memerlukan suatu proses dan perlu banyak latihan agar hasil simakan dapat menjadi lebih baik. Walaupun setiap manusia normal dilengkapi dengan potensi menyimak, namun belum tentu setiap orang menjadi penyimak yang baik.

Secara umum kegiatan menyimak menjadi hal yang penting, apabila ada pihak yang tidak dapat menyimak dengan baik, proses komunikasi tidak dapat berjalan lancar. Suatu komunikasi dikatakan berhasil apabila pesan yang disampaikan pembicara dapat dipahami oleh pendengarnya. Banyak dijumpai orang dapat mendengar dengan sempurna, tetapi tidak dapat memahami yang didengarnya. Oleh sebab itu, keterampilan menyimak harus dikuasai setiap orang, karena keterampilan ini penting dalam kehidupan sehari-hari.

Berdasarkan hasil penelitian yang pernah dilakukan (Rosdawita, 2013) dapat dilihat bahwa Contextual Teaching and Learning (CTL) sangat cocok digunakan untuk pembelajaran menyimak. Mahasiswa diberikan bahan simakan, kemudian mereka menjawab instrumen penelitian yang diberikan. Mahasiswa semakin terbantu dalam memahami konsep pembelajaran menyimak dan mempraktikkan pembelajaran keterampilan menyimak dengan menerapkan komponen-komponen CTL.

Berdasarkan hasil evaluasi pembelajaran menyimak diperoleh kesimpulan bahwa mahasiswa belum memahami materi yang terdapat dalam bahan ajar menyimak karena materi bahan ajar tidak terstruktur serta tidak tercantum secara jelas tujuan instruksional yang akan dicapai. Seharusnya, bahan ajar dapat memotivasi mahasiswa untuk belajar, mengantisipasi kesulitan belajar mahasiswa untuk mempelajari bahan tersebut, memberikan latihan yang banyak bagi mahasiswa, menyediakan rangkuman, dan secara umum berorientasi pada mahasiswa secara individual. Bahan 
ajar merupakan salah satu komponen pembelajaran yang mempunyai peranan penting dalam kegiatan pembelajaran. Pemilihan bahan ajar yang tepat seharusnya merupakan bagian yang harus mendapat perhatian guru dalam setiap kegiatan pembelajaran. Oleh karena itu, guru perlu mempelajari cara menetapkan bahan ajar sehingga dapat mengefektifkan pencapaian tujuan pembelajaran dalam proses belajar mengajar (Wardhani, 2015).

Ketercapaian tujuan pendidikan yang telah ditetapkan sangat ditentukan oleh beberapa faktor seperti pengajar, mahasiswa, pendekatan pembelajaran, buku ajar, dan faktor pendukung lainnya. Jika salah satu faktor tersebut tidak terlaksana, pembelajaran tidak akan berhasil dan berjalan dengan lancar. Belajar akan lebih bermakna jika siswa mengalami yang dipelajarinya, tidak hanya mengetahui saja. Konsep-konsep materi kuliah diharapkan dapat diintegrasikan dalam konteks kehidupan nyata dengan harapan mahasiswa dapat memahami yang dipelajarinya dengan lebih baik dan mudah melalui pembelajaran kontekstual (Hartoyo, 2009).

Pendekatan CTL merupakan salah satu pendekatan yang diduga dapat mengatasi permasalahan pembelajaran menyimak mahasiswa. Dengan pendekatan CTL, terjalin suasana belajar yang mengutamakan kerja sama, saling menunjang, menyenangkan, tidak membosankan, pembelajaran terintegrasi, menggunakan berbagai sumber, siswa aktif, sharing dengan teman, siswa kritis, dan guru kreatif (Hadiyanta, 2012). Mangesa (2014) menyebutkan bahwa pendekatan CTL dapat menyatukan pengetahuan dan pengalaman yang diperolehnya. Peserta didik terbiasa menemukan sesuatu yang berguna bagi dirinya sendiri dan menemukan gagasan baru yang cemerlang, bahkan dapat mengkonstruksikan pengetahuan yang ada dibenaknya melalui keterlibatan aktif dalam kegiatan belajar mengajar bersama teman sebaya.

Pada pembelajaran CTL, peserta didik menggunakan kemampuan berpikir kritis, terlibat langsung, dan ikut bertanggung jawab atas terjadinya proses pembelajaran yang efektif. Johnson (2010, p. 2) menyatakan bahwa CTL merupakan sebuah proses pembelajaran yang dapat menolong para siswa melihat makna di dalam materi akademik yang dipelajari dengan cara menghubungkan subjek-subjek akademik dengan konteks keadaan pribadi, sosial, dan budaya mereka. Berdasarkan hasil penelitian Nurseto (2006), metode CTL dapat digunakan untuk meningkatkan partisipasi mahasiswa dalam diskusi, kualitas pemaparan hasil diskusi, cara mahasiswa menyampaikan ulasan deskripsi secara lisan, serta kemampuan mahasiswa mengkonstruksi konsep. Sesuai dengan konsep yang dikemukakan oleh Rusman (2011, p. 171) ciri khas CTL ditandai oleh tujuh komponen, yaitu konstruktivisme, menemukan, bertanya, masyarakat belajar, pemodelan, refleksi, dan penilaian yang otentik. Buku ajar berbasis pendekatan CTL pada Mata Kuliah Pengajaran Keterampilan Menyimak diharapkan dapat mengembangkan keterampilan menyimak mahasiswa. Dengan demikian, untuk mengoptimalkan kemampuan menyimak mahasiswa perlu dikembangkan buku ajar pengajaran keterampilan menyimak berbasis pendekatan CTL.

\section{METODE}

Jenis penelitian ini adalah penelitian pengembangan. Model pengembangan yang digunakan dalam penelitian ini adalah model pengembangan ADDIE, yaitu analisis, perancangan, pengembangan, implementasi, dan evaluasi (Pribadi, 2009, p. 129). Pemilihan model ini didasari atas 
pertimbangan bahwa model ini dikembangkan secara sistematis dan berpijak pada landasan teoretis desain pembelajaran. Model ini disusun secara terprogram dengan urutan-urutan kegiatan yang sistematis dalam upaya pemecahan masalah belajar yang berkaitan dengan sumber belajar yang sesuai dengan kebutuhan dan karakteristik pembelajar (Tegeh \& Kirna, 2013). Tahap penelitian dilakukan sampai pada tahap pengembangan karena sesuai dengan fokus dan tujuan penelitian. Sama halnya yang telah dilakukan sebelumnya, penelitian pengembangan dengan menggunakan metode Four-D dilakukan sampai pada tahap pengembangan (Alfianika \& Marni, 2019). Penelitian ini bertujuan untuk mengembangkan buku ajar pembelajaran menyimak berbasis CTL untuk mahasiswa Prodi Pendidikan Bahasa dan Sastra Indonesia STKIP PGRI Sumatera Barat yang valid, praktis, dan efektif. Rancangan penelitian selengkapnya dapat diuraikan pada prosedur berikut.

Tahap analisis (analyze) merupakan tahap yang bertujuan untuk melihat kondisi di lapangan yang berkaitan dengan proses belajar mengajar. Proses yang dilakukan adalah menganalisis bahan ajar yang digunakan, analisis karakteristik mahasiswa, dan wawancara dengan teman sejawat. Tahap perancangan (design)bertujuan untuk merancang perangkat pembelajaran menyimak berbasis pendektan CTL. Proses perancangan berupa penyusunan materi yang disajikan dengan KI dan KD yang telah ditetapkan, penyusunan kerangka perangkat pembelajaran menyimak, menyusun kerangka, dan mempersiapkan komponenkomponen. Tahap pengembangan (develop). Pada tahap ini, dilakukan pembuatan dan validasi buku ajar menyimak berbasis pendekatan CTL. Suatu produk dapat digunakan sesuai dengan tujuannya memerlukan uji validitas. Sugiyono (2006, p. 414) menjelaskan bahwa validitas produk dapat dilakukan dengan cara menghadirkan beberapa pakar atau tenaga ahli yang sudah berpengalaman untuk menilai produk yang dirancang tersebut. Setiap pakar diminta untuk menilai desain tersebut sehingga selanjutnya dapat diketahui kelemahan dan kekuatan produk yang dihasilkan.

Tahap pengembangan merupakan tahap akhir pada penelitian tahap 1 ini yang bertujuan untuk menghasilkan buku ajar yang telah dinilai kelayakannya oleh para ahli. Instrumen yang digunakan untuk mengukur tingkat validitas dalam penelitian ini adalah lembar validasi. Lembar validasi digunakan untuk mengetahui buku ajar berbasis pendekatan CTL valid atau tidak. Skala penilaian pada lembar validasi menggunakan skala Likert seperti yang disajikan pada Tabel 1 .

Tabel 1

Skala Likert Lembar Validasi

\begin{tabular}{llc}
\hline Simbol & \multicolumn{1}{c}{ Keterangan } & Bobot \\
\hline SS & Sangat setuju & 4 \\
S & Setuju & 3 \\
TS & Tidak setuju & 2 \\
STS & Sangat tidak setuju & 1 \\
\hline
\end{tabular}

Sumber: Sugiyono (2006, p. 135)

Teknik pengumpulan data dalam penelitian meliputi telaah bahan ajar oleh validator (ahli buku ajar dan ahli materi) yang diukur menggunakan skala likert. Adapun teknis analisis data dalam penelitian ini adalah telaah buku ajar yang dilakukan oleh para ahli/validator dengan langkah-langkah memberikan skor untuk setiap item jawaban, sangat setuju (4), setuju (3), tidak setuju (2), dan sangat tidak setuju (1). Menjumlahkan skor total tiap validator untuk semua indikator dan pemberian nilai validitas. Hasil yang diperoleh diinterpretasikan dengan 
menggunakan kriteria yang disajikan pada Tabel 2.

Tabel 2

Kategori Validitas Perangkat Penilaian

\begin{tabular}{ll}
\hline \multicolumn{1}{c}{ Nilai $(\%)$} & \multicolumn{1}{c}{ Kategori } \\
\hline $80<V \leq 100$ & Sangat valid \\
$60<V \leq 80$ & Valid \\
$40<V \leq 60$ & Cukup valid \\
$20<V \leq 40$ & Kurang valid \\
$V \leq 20$ & Tidak valid \\
\hline
\end{tabular}

Sumber: Dimodifikasi dari Riduwan

(2011, p. 89)

Pada tahap Implementasi dilakukan uji kepraktisan terhadap buku ajar pembelajaran menyimak. Produk dikatakan mempunyai nilai kepraktisan yang tinggi dan mudah digunakan.

Tahap terakhir adalah evaluasi. Pada tahap ini dilakukan penilaian terhadap keefektifan produk yang dibuat. Efektivitas buku ajar menyimak dapat dilihat dari aktivitas dan hasil belajar mahasiswa. Data mengenai aktivitas mahasiswa didapatkan dari lembar observasi aktivitas yang diisi oleh observer ketika proses pembelajaran berlangsung. Hasil belajar didapatkan dari hasil tes yang diberikan.

\section{HASILPENELITIANDANPEMBAHASAN}

Berdasarkan analisis data yang telah dilakukan dapat disimpulkan bahwa buku ajar keterampilan menyimak berbasis CTL telah valid, praktis, dan efektif digunakan dalam pembelajaran menyimak. Analisis data dapat dijelaskan melalui tiga tahap, yaitu pendefinisian (define), perancangan (design), dan tahap pengembangan (develop).

Pelaksanaan pengembangan buku ajar menyimak berbasis CTL diawali dengan tahap analisis. Hal yang dilakukan pada tahap ini adalah melihat kondisi awal tentang pembelajaran pengajaran keterampilan menyimak. Tahap ini bertujuan untuk mengetahui permasalahan mendasar yang diperlukan untuk menyiapkan bahan ajar.

Langkah analisis melalui dua tahap yaitu tahap analisis masalah dan analisis kebutuhan. Proses analisis masalah dilakukan berdasarkan hasil pengamatan langsung dan analisis hasil wawancara. Hasil analisis masalah yang didapatkan pada perkuliahan pengajaran keterampilan menyimak Program Studi Pendidikan Bahasa dan Sastra Indonesia STKIP PGRI Sumatera Barat Tahun Ajaran Semester Ganjil 2015/2016.

Proses pembelajaran berdasarkan pengamatan langsung. Mata kuliah ini diisi dengan kegiatan praktikum dan teoretis sehingga pembelajarannya tidak hanya sekedar teoretis tetapi juga melakukan kegiatan praktikum di laboratorium menyimak. Pada kegiatan teoretis bahan ajar yang digunakan hanya mengandalkan power point yang disiapkan oleh dosen, pemberian tugas yang dilakukan juga masih sebatas tugas pembuatan makalah sehingga tidak banyak mengembangkan kompetensi mahasiswa sebagai calon tenaga pendidik.

Berdasarkan hasil wawancara dengan dosen pengampu Mata Kuliah Menyimak diperoleh fakta bahwa pelaksanaan pembelajaran menyimak belum terlaksana secara efektif. Hal tersebut dikarenakan dosen pengampu belum menemukan strategi pembelajaran atau pendekatan pembelajaran yang tepat untuk mempraktikkan pembelajaran menyimak. Masih banyak ditemui mahasiswa yang belum dapat menyimak pembelajaran dengan baik. Mahasiswa belum memahami materi yang terdapat dalam bahan ajar menyimakdan keseluruhan materi menyimak tergolong sulit karena mahasiswa belum memahami konsep pengajaran menyimak dengan baik. Hal itu disebabkan karena berbagai faktor, 
di antaranya materi yang terdapat di dalam buku ajar kurang lengkap sehingga penguasaan terhadap materi pelajaran kurang sepenuhnya berhasil sesuai dengan harapan dan tuntutan kurikulum.

Dilihat dari pelaksanaan kuliah, bentuk perkuliahan belum dapat membuat mahasiswa aktif dan mandiri, buku teks yang menjadi panduan bagi mahasiswa tidak dipakai oleh mahasiswa sebagaimana mestinya, soal yang ada pada buku teks sudah variatif tetapi mahasiswa kurang mampu menelaah dan mencari penyelesaian dari soal tersebut berdasarkan materi yang telah dipelajari. Mahasiswa tidak mampu memahami dan mempersentasikan kembali laporan bacaan yang telah mereka kerjakan sehingga pembelajaran menyimak tidak berlangsung dengan lancardan hasilnya tidak maksimal. Dengan kondisi demikian, alternatif solusi yang ditawarkan adalah buku ajar keterampilan menyimak berbasis pendekatan CTL yang memungkinkan mahasiswa untuk melaksanakan proses menyimak secara mandiri.

Selanjutnya, hasil analisis kebutuhan. Analisis kebutuhan merupakan langkah yang diperlukan untuk menentukan kemampuan-kemampuan atau kompetensi yang perlu dipelajari oleh mahasiswa untuk meningkatkan prestasi belajar. Hal ini dapat dilakukan apabila program pembelajaran dianggap sebagai solusi dari masalah pembelajaran yang sedang dihadapi. Tuntutan Kurikulum Pendidikan Nasional 2009 Strata Satu Program Studi Pendidikan Bahasa dan Sastra Indonesia adalah untuk memberikan dasar-dasar agar mahasiswa mampu menyimak dengan baik. Untuk itu, penyusunan kurikulum dititikberatkan kepada pokok bahasan yang berhubungan dengan keterampilan yang langsung dapat diterapkan. Kurikulum yang digunakan dalam pembelajaran keterampilan menyimak di Prodi Pendidikan Bahasa dan
Sastra Indonesia adalah kurikulum berbasis KKNI. Lingkup kajian materi pada mata kuliah Keterampilan Menyimak adalah mahasiswa memahmi teori menyimak dan terampil menyimak. Topik bahasannya meliputi hakikat menyimak, gangguan proses menyimak, merancang latihan menyimak dalam tataran kebahasaan, pengembangan metode, dan materi pembelajaran keterampilan menyimak di sekolah. Topik-topik tersebut di antaranya yang akan disajikan dalam buku ajar yang dikembangkan.

Berdasarkan analisis kebutuhan mahasiswa didapatkan secara garis besar kebutuhan mendasar mahasiswa adalah buku ajar yang menarik dan efektif. Selama ini, mahasiswa belajar hanya dari buku teks dan bahan ajar yang kurang membuat mahasiswa berminat belajar. Dengan demikian, buku ajar menyimak berbasis pendekatan CTL dirancang agar dalam proses pembelajaran mahasiswa turut aktif dan berpartisipatif untuk menciptakan suasana yang kondusif. Materi pembelajaran menyimak dapat dikuasi oleh mahasiswa dan kompetensi yang diharapkan dalam perkuliahan ini dapat tercapai. Sebagaimana yang telah tercantum dalam Rencana Program dan Kegiatan Pembelajaan Semester (RPKPS) keterampilan menyimak yaitu kompetensi umum dan kompetensi khusus bahwa setelah menempuh mata kuliah ini, mahasiswa diharapkan mampu menguasai materi-materi yang disajikan dan mempraktikkannya (kompetensi hardskill) serta setelah mengikuti mata kuliah ini, mahasiswa memiliki daya juang, daya tarik, mandiri, dan kreativitas (kompetensi softskill).

Untuk mengetahui lebih jelas kebutuhan mahasiswa terhadap buku ajar, disebarkan angket kebutuhan mahasiswa terhadap buku ajar. Tabel 3 menyajikan hasil angket kebutuhan mahasiswa tersebut. 
Tabel 3

Persentase Hasil Angket Kebutuhan Mahasiswa

\begin{tabular}{|c|c|c|c|}
\hline No & Pertanyaan & $\begin{array}{l}\text { Jawaban } \\
\text { Mahasiswa }\end{array}$ & Persentase \\
\hline 1 & $\begin{array}{l}\text { Selama ini, dari manakah sumber belajar } \\
\text { pengajaran keterampilan menyimak Anda } \\
\text { dapatkan? }\end{array}$ & Buku teks & $77 \%$ \\
\hline 2 & $\begin{array}{l}\text { Setujuhkah Anda jika ada sumber belajar (buku } \\
\text { ajar) khusus pengajaran keterampilan menyimak } \\
\text { yang dapat dijadikan panduan? }\end{array}$ & Setuju & $100 \%$ \\
\hline 3 & $\begin{array}{l}\text { Menurut Anda, bagaimana cara memaparkan } \\
\text { materi pengajaran keterampilan menyimak? }\end{array}$ & Singkat dan padat & $97 \%$ \\
\hline 4 & $\begin{array}{l}\text { Setujukah Anda jika dalam penyajian buku ajar } \\
\text { digunakan metode pembelajaran? }\end{array}$ & Setuju & $100 \%$ \\
\hline 5 & $\begin{array}{l}\text { Materi apa sajakah yang cocok dipaparkan } \\
\text { dalam buku ajar? }\end{array}$ & $\begin{array}{l}\text { Semua materi yang } \\
\text { sesuai dengan } \\
\text { silabus }\end{array}$ & $90 \%$ \\
\hline 6 & $\begin{array}{l}\text { Contoh soal yang seperti apa yang sesuai } \\
\text { dalam pembelajaran pengajaran keterampilan } \\
\text { menyimak? }\end{array}$ & $\begin{array}{l}\text { runtut dan mudah } \\
\text { dipahami }\end{array}$ & $70 \%$ \\
\hline 7 & $\begin{array}{l}\text { Menurut Anda, jenis evaluasi bagaimanakah } \\
\text { yang cocok digunakan dalam buku ajar } \\
\text { pengajaran keterampilan menyimak? }\end{array}$ & Uraian & $60 \%$ \\
\hline 8 & $\begin{array}{l}\text { Apakah harapan Anda terhadap bahan ajar } \\
\text { pengajaran keterampilan menyimak yang } \\
\text { dikemas dalam bentuk buku? }\end{array}$ & $\begin{array}{l}\text { Harapannya agar } \\
\text { bahan ajar dapat } \\
\text { dipergunakan dan } \\
\text { terlihat lebih simpel }\end{array}$ & $80 \%$ \\
\hline 9 & $\begin{array}{l}\text { Apakah perlu dijelaskan mengenai pengertian } \\
\text { pengajaran keterampilan menyimak dan teori } \\
\text { dasar menyimak? }\end{array}$ & Perlu & $97 \%$ \\
\hline
\end{tabular}

Berdasarkan hasil analisis terhadap angket kebutuhan mahasiswa terhadap buku ajar keterampilan menyimak diperoleh kesimpulan bahwa mahasiswa Program Studi Pendidikan Bahasa dan Sastra Indonesia STKIP PGRI Sumatera Barat $100 \%$ setuju jika dalam penyajian buku ajar digunakan metode pembelajaran. Mahasiswa 97\% setuju bahwa perlu dijelaskan mengenai pengertian pengajaran keterampilan menyimak dalam buku ajar karena materi dasar yang harus dikuasai mahasiswa. Mahasiswa 97\% setuju cara memaparkan materi pengajaran keterampilan menyimak secara singkat dan padat.

Berdasarkan hasil analisis buku teks yang ada selama ini tidak digunakan secara maksimal oleh mahasiswa dan hanya menggunakan catatan yang diberikan oleh dosen tanpa membuka dan mempelajari dari buku teks tersebut. Selain buku teks, pada Mata Kuliah Pengajaran Menyimak belum ada buku ajar yang mampu membuat 
mahasiswa berpartisipasi secara aktif sehingga dapat memahami materi yang telah dipelajari.

Sebelum buku ajar dirancang, dilihat karakteristik mahasiswa yang mengikuti perkuliahan menyimak adalah mahasiswa tahun pertama. Perkuliahan ini berada pada semester satu dengan usia rata-rata 18-19 tahun. Kondisi demikian dapat disimpulkan bahwa pada usia tersebut sebagian besar mahasiswa lebih suka dengan pembelajaran yang bersifat aktif daripada pasif. Jika mahasiswa hanya menerima penjelasan teori dari dosen, hal tersebut akan menimbulkan rasa bosan, tidak serius, dan tidak mampu memahami teori yang diberikan. Mahasiswa mudah beradaptasi dengan lingkungan, bila ada hal baru dalam kelas, misalnya teknik, strategi, metode, dan pendekatan pembelajaran, mahasiswa cenderung antusias dalam mengikuti pembelajaran.

Penelitian Ulya, Irawati, dan Maulana (2016) menunjukkan bahwa dengan menerapkan pendekatan kontekstual siswa menjadi termotivasi untuk belajar lebih baik karena kegiatan pembelajaran dengan pendekatan kontekstual akan lebih variatif dan menantang siswa untuk mampu berpikir tingkat tinggi. Selain itu, sesuai dengan harapan Kurikulum 2004, yaitu menerapkan berbagai strategi dan model pembelajaran yang efektif, kontekstual, dan bermakna. Pendekatan dan strategi pembelajaran hendaknya mengikuti pedagogi secara umum, yaitu pembelajaran diawali dari yang mudah ke yang sulit, dari materi konkrit ke yang abstrak, dari yang sederhana ke yang kompleks, dengan menggunakan berbagai sumber belajar.

Belajar akan lebih bermakna bagi siswa apabila mereka aktif dengan berbagai cara untuk mengkonstruksi atau membangun sendiri pengetahuannya (Hutagaol, 2013). Hal tersebut mendukung diterapkannya pembelajaran dengan buku ajar berbasis pendekatan CTL. Mahasiswa lebih antusias belajar secara mandiri dan bersaing dengan temannya. Hal itu terlihat ketika pembelajaran berlangsung, mahasiswa antusias dengan tugas mandiri yang dikerjakan dalam kelas. Namun demikian, mahasiswa juga dapat bekerja sama dengan baik ketika ada penugasan kelompok. Hal tersebut memudahkan mahasiswa dalam memahami materi-materi pada pembelajaran menyimak. Kondisi karakteristik mahasiswa seperti yang telah diuraikan di atas, mendukung keberterimaan terhadap buku ajar menyimak berbasis pendekatan CTL yang dikembangkan.

Tahap selanjutnya adalah desain. Desain merupakan langkah kedua dari model pengembangan ADDIE. Hasil dari kegiatan pada tahap perancangan (design) adalah sebagai berikut. Pertama, hasil pemilihan pendekatan. Pemilihan pendekatan pembelajaran untuk mahasiswa tidak hanya didasarkan pada materi yang disampaikan tetapi juga mempertimbangkan kebutuhan mahasiswa. Mahasiswa Prodi Pendidikan Bahasa dan Sastra Indonesia adalah mahasiswa yang berada dalam masa perkembangan yang tidak semua senang membaca. Menumbuhkan minat baca mahasiswa diperlukan buku ajar yang berbeda dari buku yang biasa digunakan. Dengan demikian, dipilih buku ajar berbasis CTL yang mengaitkan dengan kehidupan mahasiswa secara langsung. Setiap bidang studi yang diajarkan mempunyai prinsip pembelajaran yang berbeda. Perencanaan pembelajaran meliputi standar kompetensi, kompetensi dasar, indikator, materi pokok, media pembelajaran, sumber pembelajaran, model dan strategi pembelajaran serta kegiatan pembelajaran. Kedua, hasil rancangan awal. Perancangan awal yang dilakukan pada penelitian ini yaitu menyusun silabus, RPKPS, dan 
buku ajar berbasis contextual teaching and learning.

Setelah tahap analisis selesai, selanjutnya dilakukan tahap perancangan. Tahap ini bertujuan untuk merancang dan menyiapkan kegiatan pembelajaran serta menyusun format buku ajar. Hasil dari tahap perancangan adalah buku ajar menyimak berbasis pendekatan CTL. Rincian tahap perancangan yang dilakukan meliputi rancangan materi, rancangan pendekatan berbasis CTL, dan rancangan format.

Langkah pertama yang dilakukan untuk merancang buku ajar adalah menentukan materi pokok yang disesuaikan dengan kompetensi dasar dan indikator yang telah dirumuskan. Materi pokok tersebut bertujuan membantu mahasiswa dalam menyelesaikan indikator pembelajaran dan menambah wawasan mahasiswa. Adapun materi yang disajikan dalam buku ajar yang dikembangkan antara lain hakikat menyimak, proses kognisi dan faktor yang mempengaruhi menyimak, klasifikasi menyimak, landasan kurikuler dan teoretis pembelajaran keterampilan menyimak, perancangan, pengevaluasian, pengembangan media pembelajaran keterampilan menyimak, penelitian bidang pembelajaran keterampilan menyimak.

Pengembangan buku ajar ini, selain merancang materi juga dirancang bentuk latihan mandiri dan soal uji kompetensi sebagai salah satu syarat ketuntasan belajar mahasiswa. Latihan mandiri diberikan pada mahasiswa dalam bentuk penugasan. Mahasiswa ditugasi merumuskan dua judul penelitian, rumusan masalah, dan garisgaris besar proposal penelitian tentang pembelajaran keterampilan menyimak. Soal uji kompetensi disajikan dalam tiap pelajaran dalam bentuk pilihan ganda. Selain itu, mahasiswa juga diberikan bentuk latihan menyimak berupa memindai angkaangka dan tabel, menyimak komprehensif, menyimak grafik dan denah, serta menyimak wawancara, apresiasi puisi, dan menyimak berita.

Buku ajar yang dikembangkan disusun berdasarkan pendekatan CTL. Penyusunan ini didasarkan pada langkahlangkah pembelajaran berbasis CTL yang tampak pada penyampaian materi yang terdapat di dalamnya. Artinya, buku ajar ini ini dirancang tidak hanya memuat ringkasan materi dan evaluasi, tetapi juga membuat cara mahasiswa mengkonstruksi pengetahuannya karena materi yang lengkap dan disusun secara gradasi. Penyusunan buku ajar dengan langkahlangkah ini diharapkan dapat membawa mahasiswa ke dalam pembelajaran berbasis CTL. Ciri khas CTL ditandai oleh tujuh komponen utama yaitu konstruktivisme, menemukan, bertanya, masyarakat belajar, pemodelan, refleksi, dan penilaian yang otentik.

Buku ajar berbasis pendekatan CTL ini disusun berdasarkan format buku ajar dengan mempertimbangkan keefisienan dan keefektifan proses pembelajaran yang selanjutnya dituangkan dalam beberapa bagian, yang meliputi halaman sampul, halaman pendukung (kata pengantar, daftar isi, daftar tabel, daftar pustaka, dan tentang penulis), dan halaman isi. Pada halaman isi, buku ajar berisi standar kompetensi yang akan dicapai (SK), kompetensi dasar (KD), tujuan pembelajaran, pendekatan yang digunakan, materi, latihan, rangkuman, tes/ evaluasi, kunci jawaban, dan daftar pustaka.

Penggunaan buku ajar akan memudahkan dosen dalam perkuliahan dengan memberikan kesempatan kepada mahasiswa untuk mengkonstruksi pengetahuan dan pengalaman mereka sendiri dengan terlibat aktif dalam proses perkuliahan. Materi kegiatan belajar tersebut dibuat sesuai dengan Satuan Acara Perkuliahan (SAP) untuk masing-masing pertemuan. Buku 
ajar didesain secara lengkap dan menarik diharapkan dapat memotivasi mahasiswa untuk belajar.

Setelah melaksanakan tahap pendefinisian dan perancangan, selanjutnya dilakukan tahap pengembangan (develop). Kegiatan dalam tahap pengembangan meliputi validasi buku ajar. Validasi buku ajar bertujuan untuk menilai kelayakan buku ajar sebelum diujicobakan. Pengembangan materi pembelajaran menyimak dikatakan layak untuk diujicobakan apabila telah dinilai. Adapun aspek-aspek yang dinilai pada buku ajar berbasis CTL ini adalah aspek kelayakan isi (materi), aspek bahasa, aspek penyajian, dan aspek kegrafikaan.

Berdasarkan uji validasi yang dilakukan oleh dua orang ahlididapatkan penilaian berkaitan dengan aspek kelayakan isi, bahasa, penyajian, dan kegrafikaan. Bahan ajar dapat dikatakan berkualitas jika memenuhi empat unsur kelayakan tersebut. Kelayakan isimerupakan penilaian terhadap isi materi pembelajaran yang disajikan dan harus memenuhi tiga indikator yaitu adanya kesesuaian uraian materi dengan Standar Kompetensi dan Kompetensi Dasar, keakuratan materi, dan materi pendukung pembelajaran. Penilaian kelayakan bahasa merupakan penilaian terhadap bahasa pada bentuk penyajian dari bahan ajar. Penilaian kelayakan kegrafikan merupakan penilaian terhadap tampilan secara grafika dan tampilan bahan ajar. Hasil validasi ahli dan praktisi secara umum dapat dilihat pada Tabel 4.

Berdasarkan hasil validasi pada aspek kelayakan isi yaitu mempunyai rata-rata 78,29 (valid) dapat dikatakan bahwa buku ajar Menyimak telah mempunyai kesesuaian isi dengan kompetensi yang akan dicapai. Ini dapat dikatakan bahwa buku ajar menyimak dapat digunakan untuk membantu siswa mencapai kompentensi pembelajaran .

Hasil validasi pada aspek penyajian mempunyai rata-rata 77,00 (valid). Ini berarti buku ajar menyimak telah mempunyai komponen-komponen yang lengkap dan telah disajikan berdasarkan komponenkomponen CTL (konstruktivisme, inkuiri, pemodelan, dan bertanya).Hasil validasi pada aspek kebahasaan dan kegrafikaan yaitu rata-rata 81,25 dan 85,41. Keduanya termasuk pada kriteria sangat valid. Ratarata keseluruhan 80,48 (sangat valid). Ini berarti bahwa buku ajar menyimak telah menunjukkan keterbacaan yang baik dan sesuai kaidah bahasa Indonesia. Buku ajar Menyimak mempunyai kualitas ukuran/ format dan desain yang baik.

Tahapan berikutnya adalah uji coba produk. Tahap ini merupakan tahap penilaian mahasiswa terhadap buku ajar yang dikembangkan. Tahapan ini dilakukan pada penelitian tahun kedua. Adapun

Tabel 4

Hasil Validasi Ahli dan Praktisi secara Umum

\begin{tabular}{clll}
\hline \multirow{2}{*}{ No } & \multicolumn{1}{c}{ Aspek yang diamati } & $\begin{array}{c}\text { Rata-rata } \\
\text { Presentase }\end{array}$ & \multicolumn{1}{c}{ Kategori } \\
\hline 1 & Aspek kelayakan isi & 78,29 & Valid \\
2 & Aspek kelayakan bahasa & 81,25 & sangat valid \\
3 & Aspek kelayakan penyajian & 77,00 & Valid \\
5 & Aspek kegrafikan & 85,41 & sangat valid \\
\hline & Nilai secara umum & 80,48 & sangat valid \\
\hline
\end{tabular}


hasil penelitian pada tahun pertama, telah sampai pada validasi intrumen penelitian berupa angket, dan dapat disimpulkan bahwa instrumen sudah valid. Tahap selanjutnya adalah tahap implementasi, yaitu uji kepraktisan terhadap buku ajar pembelajaran Menyimak berupa uji coba terbatas pada mahasiswa yang telah mengambil Mata Kuliah Pengajaran Keterampilan Menyimak pada pertengahan bulan September 2016. Pelaksanakan perkuliahan dengan menggunakan buku ajar diamati efektivitas, yakni dengan mengamati aktivitas, menyebarkan angket motivasi, dan melihat hasil belajar yang diperoleh mahasiswa. Selanjutnya tahap evaluasi, yaitu uji efektivitas perangkat pembelajaran yang dibuat. Berdasarkan hasil analisis data pengamatan aktivitas mahasiswa selama perkuliahan menunjukkan bahwa perkuliahan dengan menggunakan buku ajar menyimak telah mendorong meningkatnya aktivitas belajar mahasiswa.

Tabel 5 memperlihatkan bahwa ratarata penilaian responden terhadap buku ajar adalah 94,12. Ini berarti bahwa buku ajar sudah praktis (dapat digunakan). Meskipun demikian, hasil wawancara dengan seluruh responden menyebutkan bahwa masih diperlukan beberapa perbaikan. Saran-saran responden adalah memberikan petunjuk penggunaan buku ajar pengajaran keterampilan menyimak berbasis CTL.

Aktivitas mahasiswa yang diamati pada penelitian ini. Visual activities, yaitu mahasiswa membaca buku ajar menyimak. Oral activities, yaitu mahasiswa bertanya (pada dosen atau mahasiswa lain. Listening activities, yaitu mahasiswa mendengar penjelasan dari dosen.Writing activities, yaitu mahasiswa mengisi bagian yang masih kosong atau latihan pada buku ajar menyimak. Mental activities, yaitu mahasiswa menanggapi, memecahkan soal, menganalisis, melihat hubungan, dan menyimpulkan pembelajaran. Emotional activities, yaitu mahasiswa bersemangat dan bersikap berani.

Hasil belajar mahasiswa yang diperoleh melalui tes awal dan tes akhir menunjukkan bahwa rata-rata 72,7 (efektif). Hal ini memperlihatkan bahwa dengan menggunakan buku ajar berbasis CTL efektif digunakan dalam pembelajaran Keterampilan Menyimak mahasiswa karena mahasiswa menjadi termotivasi dan aktif dalam belajar.

Setelah hasil analisis uji coba efektif selanjutnya perangkat pembelajaran disebarkan (digunakan) pada kuliah Pengajaran Keterampilan Menyimak. Diseminasi dilaksanakan setelah buku ajar pengajaran keterampilan menyimak dinyatakan sudah valid, efektif, dan praktis. Mencetak dalam

Tabel 5

Hasil Penilaian Responden Kepraktisan Buku Ajar

\begin{tabular}{ccc}
\hline \multirow{2}{*}{ Responden } & \multicolumn{2}{c}{ Rata-Rata Penilaian Responden Uji Coba Buku Ajar Berbasis CTL } \\
\cline { 2 - 3 } & Aspek A & $\begin{array}{c}\text { Aspek B } \\
\text { (Kemudahan Penggunaan) }\end{array}$ \\
\hline 1 & 93,65 & 92,86 \\
2 & 90 & 100 \\
\hline Rata-rata & 91,82 & 96,43 \\
\hline Rerata & \multicolumn{3}{c}{94,12 (sangat praktis) } \\
\hline
\end{tabular}


bentuk buku ajar yang mempunyai ISBN dan disebarluaskan pada mahasiswa Prodi Pendidikan Bahasa dan Sastra Indonesia STKIP PGRI Sumbar dan mahasiswa Jurusan Pendidikan Bahasa dan Sastra Indonesia Universitas Negeri Padang.

\section{SIMPULAN}

Berdasarkan hasil penelitian, diperoleh kesimpulan sebagai berikut. Pertama, buku ajar menyimak berbasis CTL yang dikembangkan sudah valid baik dari segi isi maupun konstruk. Kedua, buku ajar menyimak berbasis CTL yang dikembangkan sudah memenuhi kriteria praktis baik dari segi keterlaksanaan, kemudahan, dan waktu yang diperlukan. Hal ini dapat dilihat dari prediksi uji kepraktisan oleh para ahli dan data empiris, yaitu data angket uji kepraktisan menurut mahasiswa. Ketiga, buku ajar menyimak berbasis CTL yang dikembangkan sudah memenuhi kriteria efektif baik menurut para ahli dan hasil belajar mahasiswa.

\section{DAFTAR PUSTAKA}

Alfianika, N., \& Marni, S. (2019). Pengembangan lembar kegiatan siswa berbasis komik pada materi menulis poster dan slogan. Jurnal Kependidikan, 3(1), 43-52. Diunduh dari https://journal.uny.ac.id/index. php/jk/article/view/13163/pdf.

Atmazaki. (2007). Kiat-kiat mengarang dan menyunting. Padang: UNP Press.

Hadiyanta, N. (2012). Penerapan model pembelajaran contextual teaching and learning (CTL) untuk meningkatkan hasil belajar PKn. Jurnal Kependidikan, 43(1), 32-38.

Hartoyo. (2009). Penerapan model pembelajaran kontekstual berbasis kompetensi untuk meningkatkan efektivitas pembelajaran. Jurnal Kependidikan, 39(1), 95-108.
Hutagaol, K. (2013). Pembelajaran kontekstual untuk meningkatkan kemampuan representasi matematis siswa sekolah menengah pertama. Infinity, 2(1), 85-99.

Johnson, E. B. (2010). Contextual teaching \& learning: Menjadikan kegiatan belajar-mengajar mengasyikkan dan bermakna. Bandung: Kaifa.

Mangesa, R. T. (2014). Implementasi pendekatan kontekstual dalam pembelajaran praktik instalasi listrik. Jurnal Kependidikan, 46(1), 110-120.

Nursaid, \& Munaf, Y. (2010). Handout perkuliahan Mata Kuliah Pengajaran Keterampilan Menyimak. Padang: FBSS UNP.

Nursaid. (2001). Pengajaran keterampilan menyimak. Padang: Jurusan Pendidikan Bahasa dan Sastra Indonesia, FBSS UNP.

Nurseto, T. (2006). Contekstual teaching and learning sebagai model pembelajaran dasar-dasar ekonomi. Jurnal Kependidikan, 36(2), 185-204.

Pribadi, B. A. (2009). Model desain sistem pembelajaran. Jakarta: PT Dian Rakyat.

Riduwan. (2011). Rumus dan data dalam aplikasi statistika. Bandung: Alfabeta.

Rosdawita. (2013). Pembelajaran menyimak berbasis pendekatan kontekstual. Jurnal Pena, 3(2), 2089-3973.

Rusman. (2011). Model-model pembelajaran, mengembangkan profesionalisme guru. Jakarta: Rajawali Pers

Salirawati, D. (2008). Pengaruh kemampuan mendengarkan dan mencatat terhadap prestasi belajar kimia. Jurnal Kependidikan, 38(1), 45-56.

Sugiyono. (2006). Metode penelitian kuantitatif, kualitatif dan $R \& D$. Bandung: Alfabeta.

Tegeh, I. M., \& Kirna, I. M. (2013). Pengembangan bahan ajar metode 
penelitian pendidikan dengan ADDIE model. Jurnal IKA, 11(1),12-26.

Ulya, I. F., Irawati, R., \& Maulana, M. (2016). Peningkatan kemampuan koneksi matematis dan motivasi belajar siswa menggunakan pendekatan kontekstual. Jurnal Pena Ilmiah, 1(1), 121-130.
Wardhani, R. (2015). Penggunaan media kartu bergambar dalam pengembangan materi ajar buku Hanyu Tingli Jiaocheng untuk mata kuliah menyimak I dan II bahasa Mandarin. Jurnal Lensa, 5(1), 41-49. 